\title{
WATER DEFLUORIDATION, WATER DENITRIFICATION AND WATER DESALINATION IN RURAL AREAS IN SOUTH AFRICA
}

\author{
J.J. Schoeman \\ Department of Chemical Engineering, Water Utilisation Division, \\ University of Pretoria \\ Pretoria, South Africa \\ japie.schoeman@up.ac.za
}

\begin{abstract}
Many borehole waters in rural areas in South Africa are unfit for human consumption because the fluoride $(>1,5$ $\mathrm{mg} / \ell)$, nitrate-nitrogen $(>6 \mathrm{mg} / \ell)$ and salinity $(>1500$ $\mathrm{mg} / \ell$ ) concentrations are too high. Ion exchange (IX) and reverse osmosis (RO) technology are available that can be used for defluoridation, denitrification and desalination of water. However, methodology, guidelines and the economics for the use of these technologies in rural areas are not readily available. Therefore, the objectives of this investigation were to develop methodology, guidelines and the economics for the defluoridation, denitrification and desalination of water in rural areas. The capital costs of ion-exchange household defluoridation and denitrification units are estimated at R5 000 each. Operational costs vary from $\mathrm{R} 0,43$ to $\mathrm{R} 3,99 / \mathrm{kl}$ depending on the feed water concentration. The capital cost of a small RO unit to produce approximately $50 \mathrm{\ell} / \mathrm{d}$ defluoridated water is estimated at approximately R3 000. (Operational cost $\mathrm{R} 3,00 / \mathrm{k} \ell$ ). The capital cost of an RO unit to produce approximately $5 \mathrm{k} \ell / \mathrm{d}$ desalinated water is estimated at approximately R20 000. (Operational cost $\mathrm{R} 1,69 / \mathrm{k} \ell$ ). The capital cost of an RO unit to produce approximately $50 \mathrm{k} \ell / \mathrm{d}$ denitrified water is estimated at approximately R150 000. (Operational cost $\mathrm{R} 2,17 / \mathrm{k} \ell$ ).
\end{abstract}

\section{KEY WORDS}

Water defluoridation, water denitrification, water desalination, rural areas, costs.

\section{INTRODUCTION}

Many borehole waters in rural areas are unfit for human consumption because the fluoride $(>1,5 \mathrm{mg} / \ell)$; nitratenitrogen $(>6 \mathrm{mg} / \ell)$ and salinity $(>1500 \mathrm{mg} / \ell)$ concentrations are too high [1]. Dental fluorosis occurs in the North West, Northern and other provinces. Dental fluorosis is especially serious in the North West Province. Skeletal fluorosis is also experienced. Dental fluorosis is costing the Government large amounts of money through dental health services annually.
High fluoride concentrations are experienced in borehole waters in the Manke (approximately $14 \mathrm{mg} / \ell$ ), Moretele (4 to $5 \mathrm{mg} / \ell$ ) and Taung districts (approximately $5 \mathrm{mg} / \ell$ ). These waters are not fit for human consumption and must be defluoridated prior to use.

High nitrate concentrations are experienced in borehole waters in the Moretele $(173 \mathrm{mg} / \ell)$ and Kudumane $(130$ $\mathrm{mg} / \ell)$ districts. These high nitrate concentrations have the potential of causing metahaemoglobemia (blood disorder known as "blue" baby) in babies [2]. The water also does not comply with the South African drinking water standards [3].

High TDS concentrations occur in borehole waters in the Kudumane and Taung districts (3000 to 6000 $\mathrm{mg} / \ell$ ). These waters also contain high fluoride and nitrate concentrations in some cases and are not fit for human consumption.

Ion exchange (IX) and reverse osmosis (RO) technology are available that can be used for water defluoridation, water denitrification and water desalination. However, methodology, guidelines and the economics of these technologies for use in rural areas are not available. Information that is lacking include [1]:
a. Regeneration conditions.
b. The most suitable adsorbents to use.
c. The most suitable low and high pressure RO
membranes to use.
d. Water pretreatment requirements.
e. Frequency of membrane cleaning.
f. Bacterial contamination of adsorbents and membranes.
g. Design of IX and RO systems to protect the systems from vandalism.
h. Economics of these processes.

Defluoridation of water will reduce dental caries among children and fluorosis in adults and animals, with positive health effects. Nitrate-nitrogen removal from 
water supplies will protect babies from metahaemoglobemia. Desalination of brackish water will provide potable water to communities. Job creation can take place where rural people will be willing to desalinate water to sell to communities. Therefore, desalination of brackish water supplies holds numerous advantages. The main objectives of this investigation were therefore to develop methodology, guidelines and the economics for water defluoridation, water denitrification and water desalination in rural areas.

Other objectives were to:

a. Demonstrate the use of the activated alumina process for water defluoridation in rural areas.

b. Demonstrate the use of strong-base anionexchange for nitrate removal in rural areas.

c. Demonstrate the use of low and high pressure $\mathrm{RO}$ for brackish water desalination $\left(\mathrm{F}, \mathrm{NO}_{3}\right.$ and TDS removal) in rural areas.

d. Determine the economics of IX and RO technology for water desalination in rural areas.

\section{WATER DEFLUORIDATION, WATER DENITRIFICATION AND WATER DESALINATION}

\subsection{Defluoridation of water using ion-exchange}

The activated alumina process is an established process for water defluoridation [4,5]. This process can be successfully used to defluoridate water from boreholes in the feed water concentration range from approximately 4 to $20 \mathrm{mg} / \ell$ to potable standards $(<1,5$ $\mathrm{mg} / \ell \mathrm{F})$. Five to 10 bedvolumes of regenerant $(1 \%$ $\mathrm{NaOH}$ ) can be used for regeneration [5]. The activated alumina, however, should always be neutralised with a dilute solution of sulphuric acid (15 BVs $0,05 \mathrm{~N})$ prior to loading.

The waste regenerant comprises approximately $4 \%$ of the treated water. This waste regenerant should be disposed of safely, preferably into lined, fenced evaporation ponds. This brine disposal method, however, may be too expensive for application in a rural area. An alternative disposal method may be to conduct the regeneration off-site at a large municipal sewerage works, where enough dilution water is available to absorb the high fluoride concentration.

The activated alumina process should only be considered for water defluoridation where the TDS concentration is less than approximately $1500 \mathrm{mg} / \ell$. The activated alumina process is not a desalination process, and will only remove fluoride from the water. Therefore, water containing high TDS (>1 $500 \mathrm{mg} / \ell$ ) and high fluoride concentrations $(>4 \mathrm{mg} / \ell)$, should be treated with RO.

\subsection{Denitrification of water using ion-exchange}

Strong-base anion-exchange is an established process for the removal of nitrates from water [6]. Borehole waters with nitrate-nitrogen concentrations in the range from 10 to $50 \mathrm{mg} / \ell$ can be successfully treated with strong-base anion-exchange for nitrate removal $(<6$ $\mathrm{mg} / \mathrm{l} \mathrm{NO}_{3}-\mathrm{N}$ in product water).

High sulphate concentrations, however, will reduce the efficiency of conventional strong-base ion-exchange resins for water denitrification, because the sulphate will be removed preferentially which will result in a reduced output for nitrate-nitrogen removal [2]. However, nitrate selective resins are available that can be used on waters with high sulphate concentrations [7].

The waste regenerant comprises approximately $4 \%$ of the treated water. This waste regenerant consists mainly of spent sodium chloride solution. This brine should be disposed of safely, preferably into lined, fenced evaporation ponds. This method of brine disposal, however, may also be too expensive for application in rural areas. An alternative way of brine disposal may be to dispose of the brine at a large sewage works where enough dilution water is available.

The ion-exchange process should work effectively for water denitrification when the TDS of the water is low $(<1500 \mathrm{mg} / \ell)$. The ion-exchange process, as the activated alumina process, is not a desalination process. Therefore, only nitrates will be removed. The removal of high TDS concentrations $(>1500 \mathrm{mg} / \ell)$ in the presence of high nitrate concentrations $\left(>10 \mathrm{mg} / \ell \mathrm{NO}_{3}\right.$ $\mathrm{N})$ will require RO desalination.

\subsection{Defluoridation, denitrification and desalination of water using RO}

Both low (approximately 4 bar) and high pressure (approximately 15 to 20 bar) RO can be successfully applied for defluoridation, denitrification and desalination of water [1]. Fluoride in the feed water concentration range from 4 to approximately $20 \mathrm{mg} / \ell$ can be effectively defluoridated to potable standards $(<1,5 \mathrm{mg} / \ell)$ with RO. Nitrate-nitrogen in the feed water concentration range from 10 to $50 \mathrm{mg} / \ell$ nitrate-nitrogen can also be effectively denitrified with RO to potable standards $\left(<6 \mathrm{mg} / \ell \mathrm{NO}_{3}-\mathrm{N}\right)$. TDS in feed waters can be effectively reduced from $10000 \mathrm{mg} / \ell$ to less than 500 $\mathrm{mg} / \ell$.

Reverse osmosis brine should be disposed of safely in lined evaporation ponds. This, however, may be expensive in a rural area. An alternative way of brine disposal may be to use the brine for stock watering 
$[1,8]$. This might be possible in the case of high TDS and high nitrate-nitrogen concentration waters. Water recovery, however, should be kept sufficiently low to make this possible. This, however, might not be possible with high fluoride-containing waters.

Reverse osmosis membranes for defluoridation, denitrification and desalination of water are available from a large variety of membrane suppliers. Desalination experts, however, should always be consulted prior to the selection of membranes for water desalination. The same applies for adsorbents to be used for defluoridation and denitrification of water.

Pretreatment of water prior to RO desalination should be kept as simple as possible. Filtration of borehole water through a multi-media filter should remove most of the suspended material in the feed water. The remaining suspended material should be removed with a 5 micron cartridge filter prior to desalination. The cartridge filter should be cleaned or replaced when the pressure drop across the cartridge filters exceeds 1 bar.

\section{$2.4 \quad$ Generic guidelines}

The chemical composition of the borehole water should always be determined to determine whether potential foulants $\left(\mathrm{Fe}, \mathrm{Mn}, \mathrm{Ba}, \mathrm{Sr}, \mathrm{H}_{2} \mathrm{~S}, \mathrm{Ca}, \mathrm{SO}_{4}, \mathrm{~F}\right.$, etc.) are present and to determine at which safety water recovery levels the units can be operated at.

The bacteriological composition of the borehole water should also be determined to identify any faecal pollution.

The yield of the borehole water should be established to ensure a long, steady supply of water.

The product water should be chlorinated prior to distribution.

Raw and product water tanks should be closed to prevent dust and plant material contaminating the water.

The high pressure RO pump should be protected from damage by simple safety devices.

The ion-exchange or RO plant should be housed in a construction that can be locked.

The ion-exchange or RO plant feed and product storage tanks should be protected from damage by intruders by a wire fence.

Desalination equipment should be protected from direct sunlight to prevent degradation of PVC and other plastic components.
Taps should be provided where untreated borehole water can be collected for non-potable uses, such as washing of clothes, dishes, stock watering, brick manufacturing, etc.

Chemicals (acids, bases, anti-scalants, etc.) should be stored in a separate locked storeroom in the desalination plant housing.

Plant operators should always wear gloves and glasses when preparing chemical make-up.

Enough spare parts and chemicals should be kept in stock on site to prevent long down times.

Technicians should be identified who can help with mechanical and electrical problems, if they should occur.

A higher form of supervision over a water treatment scheme in a rural area will always be necessary. This task can be conducted by a suitable consultant.

\section{CONCLUSION}

The activated alumina process can remove fluoride in the feed water concentration range from approximately 4 to $20 \mathrm{mg} / \ell$ to less than $1,5 \mathrm{mg} / \ell$. Therefore, water of a potable quality can be produced with this process. The capital cost for a household defluoridation unit was determined at approximately R5 000 . Operational cost in the feed water concentration range from $4 ; 8$; and $20 \mathrm{mg} / \ell$ was determined at R0,43; R1,14 and R3,99/k $\ell$ of water treated.

- A strong-base anion exchanger can remove nitrate-nitrogen from approximately $44 \mathrm{mg} / \ell$ to less than $2 \mathrm{mg} / \ell$. The capital cost of a household denitrification unit was determined at approximately R5 000 . Operational cost at a feed water concentration of approximately 44 $\mathrm{mg} / \ell$ nitrate-nitrogen was determined at $\mathrm{R} 3,18 / \mathrm{k} \ell$ of water treated.

- $\quad$ Fluoride can be removed with low pressure RO in the feed water concentration range from 10 to $17 \mathrm{mg} / \ell$ to approximately $0,2 \mathrm{mg} / \ell$ in the RO permeate.

Fluoride can be removed with high pressure RO from approximately $17 \mathrm{mg} / \ell$ in the feed water to approximately $0,2 \mathrm{mg} / \ell$ in the $\mathrm{RO}$ permeate.

- $\quad$ Nitrate-nitrogen can be removed with high pressure RO from approximately $45 \mathrm{mg} / \ell$ 
nitrate-nitrogen in the RO feed to approximately $2 \mathrm{mg} / \ell$ in the RO permeate.

A feed water containing $3,98 \mathrm{mg} / \ell$ fluoride and $1624 \mathrm{mg} / \ell$ TDS can be desalinated with high pressure RO to contain almost zero fluoride and $130 \mathrm{mg} / \ell$ TDS in the RO permeate.

- A feed water containing $6,6 \mathrm{mg} / \ell$ of fluoride and $4156 \mathrm{mg} / \mathrm{l}$ of TDS can be desalinated with high pressure RO to contain less than $0,2 \mathrm{mg} / \ell$ fluoride and $188 \mathrm{mg} / \ell$ TDS in the RO permeate.

The capital cost of a small RO unit to produce approximately $50 \mathrm{l} / \mathrm{d}$ defluoridated water is estimated at approximately R3 000 . Operational cost is estimated at approximately $\mathrm{R} 3,00 / \mathrm{k} \ell$. The capital cost of an RO unit to produce approximately $5 \mathrm{k} / / \mathrm{d}$ desalinated water is estimated at approximately R20 000. Operational cost is estimated at approximately $\mathrm{R} 1,69 / \mathrm{k} \ell$. The capital cost of an RO unit to produce approximately $50 \mathrm{k} \ell / \mathrm{d}$ denitrified water is estimated at approximately R150 000 . Operational cost is estimated at approximately $\mathrm{R} 2,17 / \mathrm{k} \ell$.

\section{REFERENCES}

[1] J.J. Schoeman \& A. Steyn, Defluoridation, denitrification and desalination of water using ionexchange and reverse osmosis. WRC report No. TT 124/00 (2000). Water Research Commission, Pretoria, South Africa.

[2] M.A. Tisseau, Nitrates. In IWSA (ed) The Blue Pages. The IWSA information source on drinking water Issues. IWSA 1989.

[3] Department of Water Affairs and Forestry. South African water quality guidelines (second edition, 1996). Volume 1: Domestic use.

[4] J.J. Schoeman, Performance of a water defluoridation plant in a rural area in South Africa, Water SA, 35(1), January 2009.

[5] J.J. Schoeman \& G.R. Botha, An evaluation of the activated alumina process for fluoride removal from drinking water and some factors influencing its performance. Water SA, 11(1), January 1985.

[6] J.J. Schoeman, Nitrate-nitrogen removal with small-scale reverse osmosis, electrodialysis and ionexchange units in rural areas. Water SA, 35(5), October 2009.

[7] Water Quality Products. Nitrate removal by ionexchange, 8(4) April 2003.

[8] J.J. Schoeman \& A. Steyn, Nitrate removal with reverse osmosis in a rural area in South Africa, Desalination 155(2003), 15-16. 